\title{
IMPLEMENTING EUROPEAN AGRICULTURAL LAW IN NORTHERN IRELAND AND THE REPUBLIC OF IRELAND: A COMMON POLICY?
}

\author{
Brian Jack, School of Law, Queen's University Belfast \\ INTRODUCTION
}

Many parallels can be drawn between the agricultural industries of Northern Ireland and the Republic of Ireland. In terms of agricultural production, climatic and geographical factors dictate that grassland livestock farming predominates in both areas. ${ }^{1}$ A common history of land reform has also created similar agricultural structures. ${ }^{2}$ Farms in Northern Ireland and the Republic of Ireland are largely owner-occupied, family run businesses. Average farm sizes are similar, being 34.5 hectares in Northern Ireland and 29 hectares in the Republic of Ireland. ${ }^{3}$ These compare to average farm size of 59.3 hectares within the United Kingdom as a whole and 18.1 hectares within the European Community. ${ }^{4}$ In economic terms, agriculture's role within the economy has been gradually diminishing throughout western Europe. However, agriculture continues to play a more important economic role within both Northern Ireland and the Republic of Ireland than in many other areas.

In terms of policy regulation, the agricultural policies of both areas have been subject to the Common Agricultural Policy ('the CAP') since Northern Ireland and the Republic of Ireland joined the then European Economic Community in 1973. In the light of the similarities that exist between the agricultural industries of Northern Ireland and the Republic of Ireland, this article sets out to examine whether the introduction of the CAP can be said to have resulted in the operation of a truly common policy in both areas. The article begins by examining the development of the CAP and also the manner in which the initial policy operated. It then highlights the fact that this initial policy has been the subject of major reforms. In the light of these reforms the article proceeds to study the manner in which the current policy operates in both Northern Ireland and the Republic of Ireland. Finally the article concludes with a consideration of the possible effects of further recent reforms upon this 'common' policy.

1 Collectively beef and dairy farming account for $64 \%$ of all agricultural production in Northern Ireland and 67\% of agricultural production in the Republic of Irelandsee European Commission, The Agricultural Situation in the European Union 2001 Report (2002), para 3.1.15.

2 See JCW Wylie, Irish Land Law (3rd ed, 1999), p 27.

3 In respect of Northern Ireland, see Northern Ireland Statistics and Research Agency, Northern Ireland Annual Abstract of Statistics 2000 (2000), p 156. In respect of the Republic of Ireland, see European Commission, supra n 1, para 2.0.1.2.

4 European Commission, supra n 1, para 2.01.12. 


\section{Creating A Common Agricultural Policy}

The CAP developed gradually in the 1960s as a consequence of decisions taken within the Council of Ministers. ${ }^{5}$ The EC Treaty itself merely committed the original Member States to the future establishment of a common policy on agriculture and set out the objectives that this policy should strive to meet. ${ }^{6}$ Under Article 33 of the EC Treaty the following objectives were established: ${ }^{7}$

" (a) to increase agricultural productivity by promoting technical progress and by ensuring the rational development of agricultural production and the optimum utilisation of the factors of production, in particular labour;

(b) thus to ensure a fair standard of living for the agricultural community, in particular by increasing the individual earnings of persons engaged in agriculture;

(c) to stabilise markets;

(d) to assure the availability of supplies;

(e) to ensure that supplies reach consumers at reasonable prices."

In reality, both these objectives and the CAP that subsequently emerged were strongly influenced by the pre-existing national agricultural policies of the original Member States.

Article 34(1) of the EC Treaty provides for the CAP to operate through the "common organisation of agricultural markets." Additionally, Article 34(1) states that, depending on the product involved, this could be achieved in one of three ways:

" (a) the adoption of common rules on competition; or

(b) the compulsory co-ordination of pre-existing national market organisations; or

(c) the creation of a European market organisation."

The approach favoured by the European Community ('the Community') was to establish European market organisations ('common organisations') for particular agricultural produce. Each common organisation was established by a Council regulation, creating Community wide rules designed to govern production and trade in that particular agricultural commodity. As noted recently by McMahon, these regulations were based upon three basic principles: common prices, common financing by the Community budget and the requirement that Member States would give preference to Community produce over that from third countries. ${ }^{8}$

5 See A Fearne, "The History and Development of the CAP 1945-1990" in C Ritson and DR Harvey (eds), The Common Agricultural Policy (2 ${ }^{\text {nd }}$ ed, 1997), pp 18-21.

6 See arts 3 and 33 (ex art 39) of the EC Treaty.

7 For an analysis of these objectives see J A McMahon, "The Common Agricultural Policy: From Quality to Quantity" (2002) 53 NILQ 9 at 10.

8 Ibid, at 14 
The manner in which individual common organisations operated varied from commodity to commodity. For produce that was particularly important within the agricultural economies of the original Member States, such as cereals, dairy produce and beef, the regulations that established these common organisations set out comprehensive provisions. ${ }^{9}$ For example, in relation to cereals, Council Regulation 120/67 provided for the Council of Ministers to annually set three separate prices that would then apply within each Member State. ${ }^{10}$ A maximum price, the 'target price', established the maximum price that market prices should reach within the Community. Market prices that exceeded this target price would be regarded as being unreasonable, for both consumers and producers. ${ }^{11}$ The target price was then linked to a 'threshold price', which represented the minimum price at which produce could be imported into the Community. Agricultural commodity prices within the Community were generally higher than those that prevailed upon world markets. This stemmed from a decision taken by the Council of Ministers in 1964 to establish common Community prices for cereals at a relatively high level, in excess of world prices. ${ }^{12}$ Decisions taken by the Council in relation to other common organisations also followed this example. ${ }^{13}$ Subsequent annual reviews of the agricultural prices fixed by the Council also maintained this disparity. In this situation, the danger existed that the price of imported produce would undercut that of Community produce. To prevent this from happening the Council of Ministers annually established the 'threshold price.' This threshold price was set at a level that equalled the target price. Once the threshold price had been established the European Commission then had the task of fixing import levies that were to be added to the price of imported produce. These levies brought the price of that produce up to the level of the threshold price. Not only did this prevent imported produce from undercutting the price of Community produce, it also acted as a safety value for Community market prices. In the event that Community market prices should threaten to exceed the target price established by the Council of Ministers, they would then be restrained by the fact that these prices would then exceed that of imported produce. Finally the Council of Ministers also set an annual 'intervention price.' This was intended to represent the minimum price at which farmers would be able to earn a reasonable income. Member States were required to designate national bodies, known as 'intervention bodies', who would then purchase produce at the intervention prices, to provide either a floor for market prices or a market for produce that farmers had otherwise been unable to sell. The intervention system was also supported by a system of export refund payments. Given that Community prices were generally above world prices, export sales were only likely to be achieved at the lower world price. Exporters were therefore paid export refunds to compensate them for the

9 In respect of cereals see Council Regulation 120/67 (OJ [1967] 2269), in relation to dairy produce see Council Regulation 804/68 (JO [1968] L148/13) and in relation to beef see Council Regulation 805/68 (JO [1968] L148/24).

10 JO [1967] 2269. See further FG Snyder, Law of the Common Agricultural Policy (1985), p 74; JA Usher, Legal Aspects of the European Community (1988), p 53; and JA McMahon, Law of the Common Agricultural Policy (2000), p 47.

11 In accordance with the requirements of art 33(1)(e) of the EC Treaty.

12 R Fennell, The Common Agricultural Policy: Continuity and Change (1997), p 30.

13 Ibid. 
difference between Community prices and this lower export price. The European Community refunded Member States in respect of the expenditure that they had incurred in making eligible intervention and export refund payments.

Not all common organisations made the same comprehensive provision for farmers. Some provided a more limited range of measures in order to protect farm incomes. For example, in the case of eggs and poultry meat, the price of cereals, which form a major component of the feedstuffs for poultry, formed the bedrock for these common organisations. ${ }^{14}$ The common organisations for eggs and poultry meat did not provide any mechanism for internal price support. Instead they provided for a variable levy to be attached to the price of imported produce. This levy was calculated on the basis of a comparison, between the price on the European Community and world markets, of the cost of the amount of grain that would be required to produce a specific quantity of either eggs or poultry meat.

\section{A Common Price Policy?}

The common organisations operated on the basis that the Community would fix common prices that would apply uniformly throughout the Community. In reality, however, in the absence of a common currency, it was necessary to convert these prices into national currencies. Initially the European Community expressed agricultural prices in 'units of account'. The unit of account was an accounting device, providing a mechanism through which common prices could be calculated. One unit of account was worth 0.88867088 grammes of fine gold, the official value of the US dollar. ${ }^{15}$ Each unit of account was then translated into national currencies on the basis of the official exchange rate of each currency. ${ }^{16}$ This system therefore provided genuinely common commodity prices throughout the Community. Unfortunately this common price regime only remained in place until 1969 . In that year, as a result of political turbulence, the French Franc was devalued and the German Mark re-valued. ${ }^{17}$ For domestic political reasons the French and German governments, however, refused to immediately adjust their agricultural commodity prices to reflect these currency changes. Instead they agreed to gradually readjust these prices. This period led to the introduction of 'green currencies' in which the official exchange rates of the French and German currencies differed from the currency rates that were used to calculate the price of agricultural commodities. Also during that time, the Member States individually began to abandon the system of fixed exchange rates and adopted floating exchange rates for their currencies. ${ }^{18}$ They likewise refused immediately to adjust agricultural commodity prices

14 The common organisation for poultry eggs was first established by Council Regulation 122/67 (JO [1967] 2293) and that for poultry meat was first established by Council Regulation 123/67 (JO [1967] 2301). See further Snyder, supra n 10, p 87; Usher, supra n 10, p 85; and McMahon, supra n 10, p 50.

15 Council Regulation 129/62 (JO [1962] 2553), Art 1. See Usher, supra n 10, p106 and Snyder, supra n 10, p 106.

16 Ibid, art 2.

17 See E Neville-Rolfe, The Politics of Agriculture in the European Community (1984), p 254.

18 Ibid, p 256. 
to reflect changes in the official valuation of their currencies. Consequently, when the United Kingdom and the Republic of Ireland joined the Community, 'green currencies' were widely used. ${ }^{19}$ This remained the situation until relatively recently. In the 1980s and 1990s the Community introduced a number of legislative measures designed to reduce the gap between 'green currencies' and official market rates. ${ }^{20}$ The introduction of the single currency in 1999 meant that the twelve participating Member States would no longer need to convert Community prices into national currencies. However, for the three Member States not participating in the Euro, agricultural commodity prices were to be converted into national currencies at official market exchange rates. ${ }^{21}$ This finally spelt the end for 'green currencies'.

The stark reality is that the 'green currencies' originally utilised by Member States prevented CAP production policy from developing into a genuinely common policy. Instead they provided a mechanism whereby the Member States were able to pursue national agricultural polices within what was supposedly a common European policy. For example, by devaluing their 'green currency' rates, countries could increase the amounts received by farmers in their national currencies. Technically Member State's 'green currency' rates were fixed by the Council of Ministers, on the basis of a proposal submitted by the Commission. In practice however, individual Member States would indicate to the Council whether and to what extent they wished to amend their 'green currency' rate. ${ }^{22}$

The fact that individual Member States converted agricultural prices into national currencies at differing 'green currency' exchange rates also had the potential to cause grave trade distortion within the Community. ${ }^{23}$ The Community took direct action in an attempt to prevent this. A series of taxes and subsidies, known as monetary compensatory amounts ('mcas') were introduced in agricultural trade between Member States. ${ }^{24}$ These mcas were based upon the difference between agricultural prices when converted into national currencies at market exchange rates and at 'green currency' rates. Countries whose 'green currency' rates were above market rates (and who consequently had lower agricultural prices) would grant mcas as a subsidy on imports but apply them as a tax levied on exports ('negative mcas'). ${ }^{25}$ Conversely, countries whose 'green currency' rates were below market rates had higher agricultural prices. In these situations, mcas were charged as a

19 Indeed Council Regulation 222/73 (OJ [1973] L27/4) made provision for such 'green exchange rates' to be created for in relation to the United Kingdom and Republic of Ireland as a result of their accession to the European Community.

20 See JA Usher, EC Agricultural Law (2 $2^{\text {nd }}$ ed, 2001), p 120 and McMahon, supra $\mathrm{n}$ $10, \mathrm{p} 83$.

21 Council Regulation 2799/98 (OJ [1998] L349/1).

22 Snyder, supra n 10, p 110.

23 See D Colman and R Roberts, "The Common Agricultural Policy" in MJ Artis and N Lee (eds), The Economics of the European Union (1994), p 96.

24 Initially introduced by Council Regulation 974/71 (OJ [1971] L106/1), they became a compulsory part of the CAP under Council Regulation 2746/72 (OJ [1972] L291/148).

25 Snyder, supra n 10, p 112. 
tax levied on imports and granted as a subsidy on exports ('positive mcas'). ${ }^{26}$ These mcas remained a feature of the CAP until 1993. ${ }^{27}$ In that year, through Council Regulation 3813/92, mcas were abolished. ${ }^{28}$ It was no coincidence that the abolition of mcas at that time followed the establishment of the single market.

The practical impact of 'green currency' rates was that Member States were able to prioritise differing national policy objectives. One of the clearest examples of this can be seen in relation to the policies adopted in the Republic of Ireland and Northern Ireland. Historically both the Republic of Ireland and Northern Ireland have been net exporters of agricultural produce. In the case of the Republic of Ireland, the CAP offered the prospect of higher agricultural prices and, through the operation of intervention purchasing and export refunds, guaranteed markets. Such outcomes fully accorded with the government policy of expanding agricultural exports. ${ }^{29}$ In contrast, in Northern Ireland, government policy adopted a different view of the CAP. From the time of the accession of the United Kingdom to the Community until the introduction of the Northern Ireland Assembly in 1998, Northern Ireland had been governed by direct rule. Although Northern Ireland was an agricultural exporting region, central government policy was based upon the needs of the United Kingdom as a whole. Since the United Kingdom as a whole was a large importer of agricultural produce, government policy generally prioritised the maintenance of lower produce prices. ${ }^{30}$

In the period up to March 1979, when the Republic of Ireland joined the Exchange Rate Mechanism, the Republic of Ireland and the United Kingdom maintained parity in relation to the market rates of their currencies. However, this was emphatically not the case in relation to their green currency exchange rates. Throughout the 1970s devaluations of the green pound in the Republic of Ireland ensured that green pound exchange rates in the Republic of Ireland were consistently below those that existed in Northern Ireland. For example, one commentator points out that in 1977 agricultural prices were 25 per cent higher in the Republic of Ireland than in the United Kingdom. ${ }^{31}$ Indeed, during this period the devaluation of the 'green pound' in the Republic of Ireland was actually the largest source of price increases for agricultural produce, having greater impact even than increases in common prices agreed by the Council of Ministers. ${ }^{32}$ Ironically, as a consequence of a change of government policies in both the United

26 Ibid.

27 However, the Council of Ministers did take steps in the 1980s to reduce the discrepancies between national green currency rates and the corresponding levels of mca taxes and subsidies. See McMahon, supra n 10, p 85 and Usher, supra $\mathrm{n}$ 20, p 123.

28 OJ [1992] L387/1.

29 See S Sheehy, JT O'Brien and S McClelland, Agriculture in Northern Ireland and the Republic of Ireland (1981), $\mathrm{p} 16$.

30 See W Grant, "The Politics of the Green Pound 1974-1979" (1991) 19 JCMS 313 at 315 .

31 D Norton, "Smuggling under the Common Agricultural Policy: Northern Ireland and the Republic of Ireland" (1986) 24 JCMS 297 at 299.

32 SJ Sheehy, "The Common Agricultural Policy and Ireland" in PJ Drudy and D McAleese (eds), Ireland and the European Community (1984), p 85. 
Kingdom and the Republic of Ireland, this position was reversed in the early 1980s. During this period domestic agricultural prices were higher in Northern Ireland than in the Republic of Ireland.

In Northern Ireland and the Republic of Ireland, perhaps the most noticeable effect of the differing values of green currency rates and of the operation of mcas, was the encouragement that this gave to cross border smuggling of livestock. ${ }^{33}$ When green currency rates were lower, so that agricultural prices were higher in the Republic of Ireland than in Northern Ireland, exporters of livestock from the Republic of Ireland to Northern Ireland received a mca subsidy. These livestock, which had been exported through legal channels, could then be smuggled illegally back into the Republic of Ireland, thus avoiding the mca levy that was imposed on such movements. From there the animals could again be exported through legal channels and the process repeated again. In the early 1980 s, when green currency rates were higher in Northern Ireland than in the Republic of Ireland, this same process operated in the reverse direction. Additionally, the differing green currency rates also impacted upon the market itself. During the 1970s when higher agricultural prices existed in the Republic of Ireland, an incentive existed for Northern Ireland based livestock to be smuggled into the Republic of Ireland, thereby avoiding the mca levy, and sold at the higher prices prevailing in the Republic of Ireland. Consultants employed by the then Department of Agriculture for Northern Ireland predicted that this activity would lead to the closure of meat plants in Northern Ireland. ${ }^{34}$ Consequently, the Council of Ministers authorised the United Kingdom government to introduce a subsidy payment, the Meat Industry Employment Scheme (MIES), in an effort to discourage livestock smuggling from Northern Ireland. ${ }^{35}$ MIES increased the payment received by farmers whose cattle were slaughtered in abattoirs in Northern Ireland. All in all, as one commentator noted, "the CAP was being applied, contrary to the spirit of the EC Treaty, in a way that actually mitigated against market integration." 36

\section{Structural Problems In European Agriculture}

In establishing the CAP, the Community went beyond a mere price and production based policy. Article 33(2)(a) of the EC Treaty required that, in working out the CAP, the Community should also take account of, inter alia:

“. . . the particular nature of agricultural activity, which results from the social structure of agriculture and from structural and natural disparities between various agricultural regions."

One of the principal problems faced by the architects of the CAP was that a large number of marginally viable farms were in existence within the six

33 See Norton, supra $\mathrm{n} 31$.

34 PA Management Consultants Ltd, Green Pound Differential and the Northern Ireland Meat Industry. (1977) quoted in Norton, supra $\mathrm{n} 31$.

35 Council Decision, 14 ${ }^{\text {th }}$ March 1977 (unreported). See also Department of Agriculture for Northern Ireland, Northern Ireland Agriculture, $36^{\text {th }}$ Report of the Department of Agriculture (1977), p 9.

36 L McClements, "Economic Constraints" in D Watt (ed), The Constitution of Northern Ireland: Problems and Prospects (1981), p 107. 
original Member States. ${ }^{37}$ The European Commission, in putting forward its proposals for a common agricultural policy, noted that low agricultural incomes were often related to defective agricultural structures. ${ }^{38}$ The Commission sought to develop an agricultural structural policy to tackle these issues. This agricultural structural policy became known as the 'second pillar' of the CAP. In developing this policy, however, the Community had to address a number of difficult issues. In the first place, as acknowledged by Article 33(2) of the EC Treaty, the nature and extent of agriculture's structural problems varied from region to region. Additionally, most Member States had already developed their own national polices and were reluctant to agree to the creation of a common policy. For these reasons it proved difficult for the Community to develop a truly common structural policy.

Initially, under Regulation 17/64, the Community's structural policy merely sought to co-ordinate pre-existing national policies. ${ }^{39}$ The Community subsequently adopted more specific legislative measures. ${ }^{40}$ The Community's agricultural structural policy developed from a number of directives adopted by the Council of Ministers in the 1970s. In 1972 the Council adopted three structural directives. Directives 72/159 authorised Member States to provide financial assistance for investments upon farms that were suitable for development. ${ }^{41}$ Directive 72/160 authorised Member States to make financial payments to farmers and farm-workers aged between fifty-five and national retirement age. ${ }^{42}$ This directive sought to encourage the amalgamation of farms owned by retiring farmers with neighbouring farms, to create more economically viable farm units or the use of the land for non-agricultural purposes. Thirdly, directive 72/161 authorised Member States to provide socio-economic education and training to farmers. ${ }^{43}$ In addition to the 1972 directives, the Council, in 1975, adopted Directive $75 / 268$ on mountain and hill farming in less favoured areas. ${ }^{44}$ This directive sought to maintain farming and rural communities in disadvantaged rural areas and also sought to prevent damage to the countryside caused by the abandonment of agricultural land. Member States who wished to implement the directive were required to designate the areas within which it was to apply. Within these designated areas Member States were then authorised to make direct income payments to farmers or to provide financial

37 B Hill, The Common Agricultural Policy: Past, Present and Future (1984), p 26.

38 European Economic Community Commission, Proposals For The Working Out And Putting Into Effect Of The Common Agricultural Policy, In Application of Art 43 of the Treaty Establishing the European Economic Community (1960), p 15.

39 OJ [1964] 586/103.

40 In the interim period the Community rejected the European Commission proposal 'Agriculture 1980' (COM [68] 1000) which, in the period to 1980, aimed to reduce the number of people working in agriculture within the Community by five million and to reduce the amount of land used for agriculture, within the Community by five million hectares. See E Neville-Rolfe, The Politics of Agriculture in the European Community (1984), chap 9.

41 OJ [1972] L96/1.

42 OJ [1972] L96/9.

43 OJ [1972] L96/15.

44 OJ [1975] L128/1. 
grants for farm development and diversification into tourist or craft industry programmes.

Unlike in the case of expenditure upon intervention purchasing or the payment of export refunds, Member States did not obtain a full refund of their expenditure under these directives. Typically, each of the four directives provided for Member States to receive a refund of only 25 per cent of eligible national expenditure on these measures.

The three 1972 directives were intended to be inter-linked. ${ }^{45}$ Farmers could obtain advice about the viability of their farms. Those who stayed in agriculture could then take advantage of training schemes operated by their national administrations under Directive 72/161 and apply for financial assistance for farm developments available under Directive 72/159. Alternatively, farmers aged between fifty-five and national retirement age, who decided to leave the industry would be entitled to benefit from Directive 72/160. Similarly, farmers who amalgamated the lands of these out-goers into their farms could also benefit from financial assistance under directive $72 / 159$ in developing the enlarged farms. In practice, however, the Member States record in implementing these directives was somewhat fractured. Indeed one commentator has noted that:

"While eventually every Member State applied Dir. 72/159, the same is not true of the other two directives. Denmark, Greece and Luxembourg did not apply the retirement Directive; Greece, Ireland and Luxembourg did not appoint socio-economic advisors; and Greece and Luxembourg did not operate farmer-training schemes under Dir. 72/161. All three Directives were dominated by a small group of countries: the UK and Germany received over half of the funds for modernisation; Germany received 70 per cent of the retirement funds, and France received 77 per cent of the funds under directive 72/161. ${ }^{" 46}$

The extent to which particular measures were adopted within individual Member States depended upon various factors. These included the efficiency of Member States' public administrations in developing and adopting national schemes. ${ }^{47}$ An additional factor was the willingness of national treasuries to provide the necessary financial support. The net result was that the measures introduced by the 1972 directives were in practice often not widely taken up in areas that had the poorest agricultural structures. Regional variation in the operation of Community structural policy was also accentuated by additional Community measures targeted at particular regions. For example in relation to the Republic of Ireland the Community adopted Council Directive 78/628 and Council Regulation 2195/81 which sought to encourage drainage operations in less favoured areas in the west of

45 See Fennell, supra n 12, p 220.

46 Ibid, p 223.

47 Ibid, p 224 
Ireland. ${ }^{48}$ Similarly, Council Regulation $1942 / 81$ sought to stimulate agricultural development within less favourable areas of Northern Ireland. ${ }^{49}$

The four initial agricultural structural directives introduced in the 1970s remained in operation until 1985. In that year they were replaced by Council Regulation 797/85, on improving the efficiency of agricultural structures. ${ }^{50}$ This regulation itself was subsequently repealed and replaced. ${ }^{51}$ By the late 1990s the European Community's agricultural structural policy was set out in Council Regulation 950/97.52 Throughout this period, although the range of structural measures available to Member States was widened, the four measures introduced in the original directives remained at the heart of Community policy. However, the Community learned from the uneven implementation of the initial directives. Consequently, in subsequent legislation, the question as to whether to implement a particular measure remained largely at the discretion of the Member States. For example, under Council Regulation 797/85 the provision of aid for on-farm investment was the only compulsory measure that Member States were required to implement. As had originally been the case, the Community continued to provide only partial funding for these measures. The extent of the Community's contribution was, however, increased. It normally provided reimbursement of up to 50 per cent of the total cost of these measures. However, this figure was increased to 75 per cent where the expenditure had been incurred within regions designated as having objective one status. ${ }^{53}$

Although agricultural structural policy became known as the second pillar of the CAP, it can be seen that, in reality, it merely provided a common framework within which Member State practice varied widely. Equally, the European Community's agricultural structural measures must also be viewed in context. In terms of European Community expenditure, agricultural structural measures played only a peripheral role within the CAP. In 1969 the European Commission had envisaged that 30 per cent of the Community's expenditure upon agriculture would have been incurred in financing structural measures. ${ }^{54}$ In reality spending on structural measures never reached these proportions. For example in 1985 spending on

48 See Council Directive 78/628 (OJ [1978] L206/5) and Council Regulation 2195/81 (OJ [1981] L214/5).

49 OJ [1981] L197/17.

50 OJ [1985] L93/1.

51 Council Regulation 797/85 (OJ [1985] L93/1) was originally replaced by Council Regulations 2328/91 (OJ [1991] L218/1) and 2079/92 (OJ [1992] L215/91) which themselves were subsequently repealed and replaced by Council Regulation 950/97 (OJ [1997] L142/1).

52 Council Regulation 950/97 (OJ [1997] L142/1) on improving the efficiency of agricultural structures.

53 See Council Regulation 2052/88 (OJ [1988] L185/9) on the task of the Structural Funds, art 13. By virtue of art 8 of this Regulation objective one regions were those "whose per capita GDP. . . is less than $75 \%$ of the Community average." Both Northern Ireland and the Republic of Ireland were designated as objective one areas under the regulation.

54 European Commission, "Memorandum on the Reform of Agriculture in the European Economic Community” (1969) Bulletin Supplement 1, p 29. 
Community expenditure on structural measures accounted for only 3.5 per cent of Community spending on agriculture. ${ }^{55}$

\section{Reforming The CAP}

Since its inception, the CAP has undergone a number of reforms. During the 1980s reforms were introduced within individual common organisations and with respect to individual structural measures. These reforms were largely driven by the Community's recognition of the fact that agricultural production was exceeding its market requirements in virtually every sector. In this position the Community's commitment to fund both the purchase of surplus produce and the payment of export refunds had a profound effect upon the Community budget. For example, by 1980 Community expenditure on the CAP was accounting for some 73 per cent of the entire Community budget. ${ }^{56}$ Perhaps the best known reform from this period, that is still in existence today, was the introduction of the milk quota in $1984 .{ }^{57}$ Indeed the introduction of the milk quota provides a further example of how national disparities can arise within the CAP. In this case, negotiators representing the Republic of Ireland secured additional quota rights for its farmers, on the grounds of the importance of the dairy sector within the national economy. This caused political controversy in Northern Ireland, where the United Kingdom government initially failed to secure similar concessions for farmers there. ${ }^{58}$

In addition to the measures adopted in the 1980s, two substantive reforms have occurred more recently. These were the MacSharry reforms adopted in the 1992 and the 'Agenda 2000' reform measures adopted in 1999. ${ }^{59}$ Unlike previous reforms, these reform packages each introduced measures that simultaneously affected a number of areas of agricultural policy. They also varied from previous reforms in that they were profoundly affected by both agricultural issues and also by broader reforms within Community policy making. In relation to the agricultural policy issues, both the 1992 and 1999 reform packages continued to reflect the Community's desire to limit the influence of the CAP upon the Community budget. Additionally they were also influenced by international negotiations concerning agricultural trade. In 1992 the MacSharry reforms sought to prepare the CAP for commitments given in international trade negotiations that later culminated in the 1994 GATT Agriculture Agreement. ${ }^{60}$ Subsequently the 'Agenda 2000' reforms

55 Calculated by the author from European Commission, The Agricultural Situation in the Community 1987 Report (1988), p T83.

56 Colman and Roberts, supra $\mathrm{n} 23, \mathrm{p} 99$.

57 See Council Regulation 856/84 (OJ [1984] L90/10) and Council Regulation 857/84 (OJ [1984] L90/13).

58 See P Hainsworth, "The European Community as a Policy Arena in Northern Ireland" in ME Connolly and S Loughlin (eds), Public Policy in Northern Ireland: Adoption or Adaptation? (1992), p 93.

59 The MacSharry reforms were named after Raymond MacSharry, the European Commissioner for Agriculture at the time they were negotiated. 'Agenda 2000' was the title of a package of reform proposals initially published by the European Commission in 1997.

60 For a detailed analysis see T Josling, S Tangermann and T Warley, Agriculture in the GATT (1996). 
were also partially motivated by the fact that further international discussions were due to take place. The 'Agenda 2000' reform measures were also influenced by a desire to reform the CAP ahead of the eastern expansion of the EC and by recognition of a need to reform agricultural structural policy to reflect the fact that agriculture was no longer the predominant employer in most rural areas. ${ }^{61}$ The reforms also coincided with the introduction of broader considerations that have influenced all the Community's policy areas. For example, the amendment of the EC Treaty by the Single European Act in 1986 imposed a requirement upon the Community to ensure that environmental protection requirements became a component of all substantive policies. ${ }^{62}$ Following subsequent amendments by the Treaty on European Union and the Treaty of Amsterdam, the EC Treaty today contains the stronger requirement:

"Environmental protection requirements must be integrated into the definition and implementation of the Community's policies ... in particular with a view to promoting sustainable development."63

Just prior to the Single European Act, the Commission itself, in conducting a comprehensive review of agricultural policy, had noted that agriculture was:

"[A] cause - and some times even as the major cause of the extinction of species of flora and fauna and of the destruction of valuable ecosystems such as wetlands, and in some cases have increased risks of ground and surface water pollution." 64

It can therefore be seen that agricultural policy reforms would have to address this issue. Similarly, the Single European Act also introduced the concept of subsidiarity, as a consideration upon which Community environmental action should be based. ${ }^{65}$ Subsequently, following the amendment of the EC Treaty by the Treaty on European Union, subsidiarity was raised to a general principle that the Community is today required to apply "in all areas which do not fall within its exclusive competence." 66 In these areas the Community should only take action "... if and in so far as the objectives of the proposed action cannot be sufficiently achieved by the Member States and can therefore, by reason of scale or effects of the proposed action, be better achieved by the Community." 67 Ironically, the European Commission initially identified the operation of the common organisations as being areas of exclusive Community competence within which the principle of subsidiarity would not apply. ${ }^{68}$ In practice, however,

61 See European Commission, Agenda 2000: Volume 1, For a Stronger and Wider Union and Vol 2, The Challenge of Enlargement, COM (1997) 2000 Final.

62 Art 130(r)(2) as inserted into the EC Treaty by the Single European Act 1986.

63 Art 6 of the Consolidated EC Treaty.

64 European Commission, Perspectives for the Common Agricultural Policy, COM (1985) 333/2 Final, p 50.

65 Art 130(r)(4) of the EC Treaty as amended by the Single European Act.

66 Art 5 of the consolidated version of the EC Treaty, as also amended by the Treaty of Amsterdam.

67 Ibid.

68 See Communication by the European Commission to the Council of Ministers and the European Parliament Outlining Proposals For The Application of the Subsidiarity Principle: Bulletin EC 2/2 10 (1992), p 121. 
the Community institutions have adopted a more liberal approach in addressing issues of subsidiarity in relation to the operation of the common organisations. In contrast considerations of subsidiarity have always been an element of the Community's agricultural structural policy. Here there was a need for Community legislation, to prevent market distortion through independent national measures. However, at the same time, the Community also needed to take account of the differing structural needs of various regions as well as Member State opposition to a centralised policy. In relation to the operation of the common organisations, the move to enable Member States to tailor policy measures to particular local circumstances was most pronounced within the Community's 'Agenda 2000' reforms. For example, in its proposals for those reforms, the European Commission noted that:

"A new more decentralised model has. . . to be developed which gives the Member States the means of settling a number of issues for themselves by taking better account of the characteristics of a given sector or a given set of local conditions.

But such a development in this direction needs to be carefully controlled so as to avoid any risk of distorting competition or renationalising the CAP.

This means that the greater freedom granted to Member States must be exercised within a framework of shared, clear and precise ground rules, using a Community financing system and based on rigorous controls." 69

\section{The Common Organisations Today}

The CAP today continues to make provision for agricultural production and trade through the operation of common organisations. Over twenty such common organisations presently exist, covering the principal sectors of agricultural production within the Community. However, the reforms referred to above have altered the manner in which individual common organisations operate. It has been noted that in both Northern Ireland and the Republic of Ireland beef farming and dairy farming are of central importance to the agricultural economy. Similarly in the Community as a whole beef and dairy produce account for 24 per cent of all agricultural production. ${ }^{70}$ As can therefore be imagined, the common organisations concerning both beef and dairy produce have both been in the forefront of the reforms.

To a large extent the reforms introduced common measures that applied equally throughout the Community. The practical effect of these measures has been to reduce the level of market protection provided to farmers. For example, as part of its GATT commitment, the Community replaced variable

69 European Commission, Proposals for Council Regulations Concerning the Reform of the Common Agricultural Policy, COM (1998) 158 Final, p 3.

70 European Commission, The Agricultural Situation in the European Union 2001 (2002), para 3.1.1. 
import levies with fixed customs duties. ${ }^{71}$ Additionally, in order to reduce the gap between agricultural prices within the Community and upon world markets, the Community lowered agricultural prices such as the intervention prices set for beef and dairy produce. Similarly, the introduction of restrictions upon the availability of intervention purchasing has transformed the intervention system into a safety net that operates in adverse market conditions, rather than simply a market for surplus produce. Following these reforms, agricultural expenditure now accounts for 47 per cent of the Community budget. ${ }^{72}$ Farmers have been compensated by the Community for these changes, through an extension in the availability of direct payments. Such payments had originally been introduced in the 1980s for sheep farmers. ${ }^{73}$ Beef farmers have also been eligible to receive a number of direct payments such as beef special premium, suckler cow premium and slaughter premium. $^{74}$ Elsewhere, arable farmers have, since 1992, been eligible to receive Area Compensatory payments. ${ }^{75}$ From 2005 a dairy premium will be introduced for dairy farmers. ${ }^{76}$ In each case, these payments are today made at fixed rates and in accordance with common criteria set out in the regulation establishing each common organisation. For example, in relation to beef farming, special beef premium is available to farmers twice in the life of up to ninety steer cattle. In contrast suckler cow premium is paid annually on the number of eligible suckler cows maintained by each farmer and slaughter premium is available in respect of eligible cattle that are either slaughtered or exported from the Community. The common nature of these payments is also emphasised by the fact that the regulations governing the operation of the common organisations generally provide that they are subject to Community state aid laws. This prevents Member States from introducing additional payments without first obtaining the approval of the

71 See Council Regulation 3290/94 (OJ [1994] L349/105) in particular Annex VII, art 14 and Annex VIII, art 10, applying respectively to the common organisations for dairy products and for beef.

72 European Commission, The Common Agricultural Policy: 2000 Review (2001), p 17.

73 The common organisation in sheepmeat was only established in 1980, under Council Regulation 1837/80 (OJ [1980] L183/1). This common organisation was distinct from the other common organisations for livestock produce in that it did not seek to support market prices. Instead a direct payment, sheep annual premium, was paid to farmers to compensate them for the difference between average market prices and a target, 'basic', price set by the Community. Recent reform of the common organisation in sheepmeat, by Council Regulation 2529/2001 (OJ [2001] L341/3), has now replaced this system with a fixed rate payment for sheep farmers.

74 The payment of direct payments to beef farmers is governed by Council Regulation 1254/99 (OJ [1999] L160/21). Originally beef special premium was introduced by Council Regulation 467/87 (OJ [1987] L48/1) to help beef farmers to adjust to restrictions that had been placed upon the availability of intervention purchasing. In the United Kingdom beef special premium was initially paid as a slaughter premium.

75 The payment of Area Compensatory payments is today governed by Council Regulation 1251/99 (OJ [1999] L160/1).

76 The intention to introduce the dairy premium in 2005 is set out in Council Regulation 1255/99 (OJ [1999] L160/48). 
European Commission. ${ }^{77}$ For example, in 1999 the United Kingdom obtained Commission approval for the implementation of the Pig Welfare Slaughter Compensation Scheme, which provided financial assistance to pig farmers in Northern Ireland after fire destroyed Northern Ireland's major pig slaughtering facility. ${ }^{78}$ Similarly, in 2000, the Republic of Ireland also obtained Commission approval for a 'Ewe Supplementary Measure', which provided farmers in western counties with a slaughter premium for mountain ewes. ${ }^{79}$

In addition to these common measures, the Community also adopted other reforms to meet its obligation to integrate environmental considerations into the operation of the common organisations and to take account of considerations of subsidiarity. ${ }^{80}$ The preponderance of social, climatic and geographical conditions that exist throughout the Community ensured that both the nature of agriculture and the environmental problems associated with it also varied widely. This limited the Community's ability to effectively integrate environmental protection considerations into the operation of individual common organisations through common measures. It is principally in these areas, therefore, that national differences have arisen in the operation of the common organisations. The Community initially granted Member States discretion to link direct payments made to sheep and beef farmers with a requirement that farmers receiving these payments should respect appropriate, nationally determined, environmental obligations. $^{81}$ In reality the United Kingdom and the Republic of Ireland were two of only three Member States to act upon this discretion. ${ }^{82}$ Subsequently, as part of the 'Agenda 2000' reforms, Council Regulation $1259 / 99$ placed an obligation upon Member States to link all direct payments made to their farmers through the CAP with the requirement that those farmers should respect appropriate environmental obligations. ${ }^{83}$ However, the Regulation provided for Member States themselves to decide upon the obligations that would be appropriate. The Regulation did, however, set out several options for these national measures. ${ }^{84}$ Member States might make the availability of direct payments conditional upon farmers observing specific environmental conditions. Alternatively, Member States could introduce compulsory environmental commitments, such as regulatory measures, that affect all farmers irrespective of whether they receive direct

77 For example, in relation to the common organisation in beef and veal, Council Regulation 1254/99 (OJ [1999] L160/21), see art 40.

78 European Commission, The Agricultural Situation in the European Union, 1999 Report (2001), p 53.

79 European Commission, The Agricultural Situation in the European Union, 2000 Report (2002), p 43.

80 See further B Jack, "Protecting the European Environment from the Community: the case of Agriculture" (2001) 3 Env LR 44.

81 For special beef premium and suckler cow premium, this discretion was introduced by Council Regulation 3611/93 (OJ [1993] L30/9). In the case of sheep annual premium the discretion was introduced by Council Regulation 233/94 (OJ [1994] L30/9).

82 See Court of Auditors, Special Report 14/2000: Greening the CAP, OJ [2000] C353/1, p 10.

83 OJ [1999] L160/113, art 3.

84 Ibid. 
payments. Thirdly the Regulation also specifies the possibility that Member States might provide financial support to farmers in return for securing the participation of those farmers upon agri-environmental management agreements. ${ }^{85}$

In both Northern Ireland and the Republic of Ireland the measures adopted have linked the availability of direct payments to an obligation that farmers should observe specific environmental conditions. However, distinctions exist between these national measures. In Northern Ireland, for example, national legislation concerning the availability of direct payments to beef and sheep farmers seeks to prevent environmental damage being caused to land either through overgrazing or the use of unsuitable supplementary feeding techniques. ${ }^{86}$ In relation to overgrazing, where officials of the Department of Agriculture and Rural Development ('DARD') believe that a parcel of land is being overgrazed, they can specify the maximum number of sheep and beef cattle that the farmer concerned will be allowed to keep on that land in the following year. This can also be renewed in subsequent years. This farmer will then only be entitled to receive direct payments in respect of the number of livestock that were specified in the DARD notification. Similarly DARD is entitled to reduce livestock payments in respect of beef cattle and sheep where it is satisfied that the farmer is using unsuitable supplementary feeding techniques which are causing vegetation damage, through excessive trampling or poaching by livestock or excessive rutting by vehicles. In contrast, in the Republic of Ireland, beef and sheep farmers are required to comply with a code of good farming practice, issued by the Department of Agriculture and Food ('DAF'), in return for receiving direct payments. ${ }^{87}$ The code of practice sets out recommendations for good practice in relation to a number of areas of farm practice, not just in relation to overgrazing and the use of supplementary feeding techniques.

Council Regulation 1259/99 also provides for Member States to decide upon the penalties that would be imposed upon farmers who failed to observe stipulated environmental conditions. ${ }^{88}$ These penalties, which could include the reduction of payments or cancellation of eligibility to receive payments, are, however, required to be appropriate to the seriousness of the ecological consequences that would result from a failure to observe these measures. ${ }^{89}$ In Northern Ireland, identical penalties are established by individual regulations. ${ }^{90}$ Where DARD inspectors determine that the number of

85 Agri-environmental management agreements are examined later in this article in relation to the operation of Community structural policy within agriculture today.

86 In relation to beef farming see the Slaughter Premium Regulations (NI) 2001 (SI 2001/199), regulations 8-9 (as amended by the Slaughter Premium (Amendment) Regulations (NI) 2003 (SI 2003/192)); the Suckler Cow Premium Regulations (NI) 2001 (SI 2001/362), regulations 5-6; and the Beef Special Premium Regulations (NI) 2001 (SI 2001/363), regulations 5-6. In relation to sheep farming see the Sheep Annual Premium Regulations (NI) 1992 (SI 1992/476) as amended by the Sheep Annual Premium (Amendment) Regulations (NI) 1994 (SI 1994/4).

87 The Department of Agriculture and Food was also previously known as the Department of Agriculture, Food and Rural Development.

88 Council Regulation 1259/99 (OJ [1999] L160/113), art 3(2).

89 Ibid.

90 In accordance with the Regulations detailed, supra $\mathrm{n} 86$. 
livestock kept upon a particular parcel of land exceed the number set out on a previous notification they are entitled to withhold, or demand the repayment of all or part of the premium payments for any particular year. In situations in which farmers are found to have used unsuitable supplementary feeding techniques then, where the farmer had not been penalised for this in the previous year, DARD has power to reduce their premium payments by 10 per cent. Where the farmer had also been penalised in the previous year, premium payments will be reduced by 20 per cent. However, where the farmer had also been penalised in each of the last two previous years premium payments will be withheld altogether. In contrast in the Republic of Ireland, where a farm inspection by DAF reveals a breach of the code of practice then the penalty imposed varies in relation to the nature of the breach. ${ }^{91}$ In some cases, for example where the inspection reveals evidence that slurry has been spread in a manner that creates a significant pollution risk, the code of practice provides for farmers to initially receive a warning. However, subsequent repeat of such practice would result in the farmer losing 10 per cent of the value of any direct payments that the farmer was entitled to receive. In other cases, such as where farm wastes are being collected or stored in a manner that creates a significant pollution risk, DAF will immediately impose this latter penalty. Alternatively the code of practice also provides for situations in which DAF will notify other authorities of situations that they discover, with the result that the farmer concerned may be prosecuted. This arises where the code of practice asks farmers to refrain from conduct which itself would amount to the commission of a criminal offence. This for example, would arise where inspectors discovered that livestock were not appropriately cared for.

In addition to the measures taken to introduce environmental protection requirements into the direct payment regime, the Community's recognition of the principle of subsidiarity has also had an impact on the operation of these payments. In particular, the Community has implemented three measures that have given Member States greater control over the level of specific payments. Previously, beef farmers had been eligible to obtain additional fixed premium payments in return for maintaining livestock densities that were less than or equal to 1.4 livestock units per hectare upon their farms. ${ }^{92}$ However, Council Regulation 1254/99 amended this to provide Member States with discretion. ${ }^{93}$ They could continue to provide extensification payments to beef farmers who maintained livestock densities that were less than or equal to 1.4 livestock units per hectare. ${ }^{94}$ Alternatively

91 Department of Agriculture, Food and Rural Development, Good Farming Practice (2001), p 11.

92 See Council Regulation 805/68 (OJ [1968] L148/24) as amended by Council Regulation 2066/92 (OJ [1992] L215/49). Livestock units are calculated by allocating the following weightings to farm animals: male cattle and heifers older than 24 months, suckler cows and dairy cows: 1.0 livestock unit; male cattle and heifers aged 6 months to 24 months: 0.6 livestock units; sheep and goats: 0.15 livestock units.

93 OJ [1999] L160/21, art 13.

94 Ibid. Member States were authorised to provide an extensification payment of $€ 100$ per suckler cow or cow eligible for special beef premium, to farmers who had maintained a livestock density of 1.4 livestock units or less throughout that year. 
Member States were also authorised to provide extensification payments to farmers who achieved more gradual reductions in their livestock densities over the period 2000 to $2002 . .^{95}$

Secondly, Council Regulation 1254/99 also introduced the concept of 'national envelopes' into the common organisation for beef. ${ }^{96}$ Direct payments are principally made upon the basis of common criteria. However, with the introduction of national envelopes, each Member State has also been allocated a specific sum of money that it could allocate to beef farmers within its borders in the manner that it felt was most appropriate to their situation. Recently Council Regulation 2529/2001 has also extended the operation national envelopes by introducing a similar measure in relation to sheep farming. ${ }^{97}$

Finally, Council Regulation 1259/99 also introduced the concept of 'modulation'. This gave Member State's discretion to reduce the value of the direct payments that would otherwise be made to their farmers. ${ }^{98}$ Monies saved by this reduction are then reallocated to rural development measures within that Member State. Given that the Community budget only provides a partial refund of Member State's expenditure upon rural development measures, this provision is designed to increase the funds that are available to national treasuries for these measures. Member States are entitled to deduct up to 20 per cent of the value of the direct payments that would otherwise be received by their farmers. ${ }^{99}$

In Northern Ireland and the Republic of Ireland there are marked similarities in the manner in which both jurisdictions have implemented both extensification and national envelope payments to beef farmers. In relation to extensification payments, both DARD in Northern Ireland and DAF in the Republic of Ireland have chosen to avail of the option to make extensification payments on the graduated scale. Therefore, for example, in 2001 the value of the extensification payments made to farmers in both jurisdictions depended upon whether the livestock densities that they had maintained were below 1.6 livestock units per hectare or were between 1.6 and 2.0 livestock units per hectare. ${ }^{100}$ Similarly the beef national envelopes available in both Northern Ireland and the Republic of Ireland have both

95 Ibid. In 2000-2001, Member States were authorised to make payments of $€ 33$ per eligible animal to farmers who maintained a livestock density of between 1.6 and 2.0 livestock units and $€ 66$ per eligible animal to farmers who maintained a livestock density of less than 1.6 livestock units per hectare. From 2002 this alternative provision then provided for Member States to make extensification payments at the rate of $€ 40$ in respect of stocking densities of between 1.4 and 1.8 livestock units and $€ 80$ for livestock densities that were less than 1.4 livestock units.

96 OJ [1999] L160/21, arts 14-20.

97 OJ [2001] L341/3, art 11.

98 OJ [1999] L160/113, art 4.

99 Ibid, art 4(2).

100 Extensification payments in Northern Ireland are governed by the Extensification Payment Regulations (NI) 2001 (SI 2001/127). In relation to the Republic of Ireland see Department of Agriculture, Food and Rural Development, Your Guide to Agenda 2000 Changes in Livestock and Arable Direct Payments located at <http://www.gov.ie/daff/Publicat/ag2000/agq5.htm〉. 
been used to provide additional payments to farmers within the slaughter premium and suckler premium schemes. ${ }^{101}$ However, a clear distinction can be drawn between national practice in Northern Ireland and the Republic of Ireland in relation to the discretion to modulate direct payments received by farmers. In the Republic of Ireland the government chose not to act upon their discretion to implement this measure. In contrast in Northern Ireland, as has been the case throughout the United Kingdom, modulation has been introduced. ${ }^{102}$ Indeed the United Kingdom treasury is providing additional funding for rural development to match that raised in Northern Ireland through the operation of modulation. Modulation was initially introduced in Northern Ireland in 2001, when direct payments to farmers were reduced by 2.5 per cent. ${ }^{103}$ This reduction was subsequently increased to 3 per cent in 2002 and 3.5 per cent in 2003. Thereafter it was intended that, from 2005, the rate of modulation will rise to 4.5 per cent. ${ }^{104}$ Overall, it was anticipated that, in the period 2001 to $2006, £ 38$ million would be deducted from direct payments in Northern Ireland and reallocated to rural development measures. ${ }^{105}$

\section{Agricultural Structural Policy Today}

As a consequence of the Community's recognition that agriculture is no longer the predominant rural employer, Council Regulation 1257/99 broadened the scope of the second pillar of the CAP. ${ }^{106}$ This aspect of the CAP no longer merely focuses upon the structural development of agriculture. Instead it has begun to provide support and encouragement for rural development, thus enabling assistance to be provided for projects that are outside agriculture. However, agriculture still forms an important element within this policy. Additionally the Community has sought to increase its expenditure within this second pillar of the CAP. Rural development measures today account for some 16 per cent of the total Community expenditure upon agriculture. ${ }^{107}$

One major change from the Community's initial structural policy for agriculture is that the Community today views agriculture as having a multifunctional role. Beyond food production, Community rural development policy now also provides support for other objectives, such as diversification into non-food crops and the protection of rural landscapes. Indeed,

101 In relation to Northern Ireland see Department of Agriculture and Rural Development Press Release 537/01, "Rogers Announces Use of Beef National Envelope Funds in 2002" and located at <http://wwwdardni.gov.uk/pr2001 /pr010537.htm>. In relation to the Republic of Ireland see Department of Agriculture, Food and Rural Development, Your Guide to the Changes in Livestock and Arable Aid Schemes (2002), p 21.

102 See Department of Agriculture and Rural Development, Our Services: Grants and Subsidies (2002) located at <http://www.dardni.gov.uk/grants and subsidies/gas 0036.htm>.

103 Ibid.

104 Ibid.

105 Ibid.

106 See, for example, European Commission, Agenda 2000 Volume 1: For a Stronger and Wider Union, COM (1997) 2000 Final, p 26.

107 European Commission, Mid-Term Review for Sustainable Agriculture, COM (2002) 394 Final, p 9. 
consistent with the Community's obligation to integrate environmental protection requirements within the CAP, this latter objective today assumes a central position within Community rural development policy.

\section{Rural Development Plans}

Council Regulation $1257 / 99$ required Member States, or their regional authorities, to design rural development plans, outlining their rural development strategy, for a seven year period from $1^{\text {st }}$ January $2000 .{ }^{108}$ These plans required the approval of the European Commission. By the end of 2000 the Member States, or their regional authorities, had submitted some sixty-nine different rural development plans to the Commission. ${ }^{109}$ As has been the case since the Community introduced a structural policy within the $\mathrm{CAP}$, the Community budget reimburses only part of the costs incurred by national authorities in implementing these rural development plans. In areas such as Northern Ireland and the Republic of Ireland that are recognised as being either objective one areas or objective one areas in recovery, the Community currently reimburses up to 75 per cent of this expenditure. ${ }^{110}$ In other areas, the Community budget will only reimburse up to 50 per cent of national outlay. ${ }^{111}$

In designing their rural development plans, Council Regulation 1257/99 sets out a menu of potential measures that national authorities could provide. Any national measures that were adopted outside of this menu would be liable to be declared illegal state aids, unless also approved by the European Commission. ${ }^{12}$ One measure was compulsory, however, and had to be included within all rural development plans, this was an agri-environmental land management scheme. ${ }^{113}$

\section{The Community's Agri-Environmental Land Management Scheme}

The origins of the agri-environmental land management scheme can be traced to Council Regulation 797/85 on improving the efficiency of agricultural structures. ${ }^{14}$ Article 19 of this Regulation gave Member States the discretion to introduce such measures within nationally designated environmentally sensitive areas. These were required to be areas of recognised ecological or landscape importance. Member States were

108 OJ [1999] L160/80, arts 40-44.

109 European Commission, The Common Agricultural Policy: 2000 Review (2001), p 13.

$110 \mathrm{Ibid}$, art 47 and see also supra n 53. Following the implementation of Council Regulation 1260/99 (OJ [1999] L161/1) only parts of the Republic of Ireland and no area of Northern Ireland still possess objective one status. However, under Art $6(1)$ of this regulation, the remaining parts of the Republic of Ireland and Northern Ireland as a whole have been designated as 'objective one areas in recovery'. As a consequence of this they will continue to be eligible to receive objective one funding until $31^{\text {st }}$ December 2005.

111 Art 47.

112 See arts 51 and 52. See also Community Guidelines for State Aid- the Agriculture Sector, OJ [2000] C 28/2.

113 OJ [1999] L160/80, art 43(2).

114 OJ [1985] L95/1. 
authorised to pay financial aids to farmers, within such areas, who undertook to farm in a manner that protected or improved the environment. Subsequently, Council Regulation 2078/92 placed a mandatory requirement upon Member States to implement agri-environmental land management schemes throughout their territories. ${ }^{115}$ This Regulation was repealed by Council Regulation 1257/99, which continues to require Member States to construct agri-environmental land management schemes. These schemes are required to promote the following objectives:

- ways of using agricultural land which are compatible with the protection and improvement of the environment, the landscape and its features, natural resources, the soil and genetic diversity;

- an environmentally-favourable extensification of farming and management of low-intensity pasture systems;

- the conversion of high nature-value farmed environments which are under threat;

- the upkeep of the landscape and historical features on agricultural land;

- the use of environmental planning in farming practice. ${ }^{116}$

The Regulation requires that farmers enter into agreements lasting at least five years under which they make agri-environmental commitments that go beyond good farming practice, which is expected of all farmers. ${ }^{117}$ In return farmers receive payments that are fixed by Member States, subject to maximum ceilings established by the Regulation. ${ }^{118}$

The large measure of discretion afforded to Member States, in devising rural development plans which best suited their needs, has created much variation in national practice. The Commission had anticipated that Council Regulation 2078/92 would result in each Member State introducing one agrienvironmental land management scheme. ${ }^{119}$ Instead, it had approved some 158 different schemes by late $1998 .{ }^{120}$ Broad differences existed between these schemes. The Court of Auditors has noted that the willingness of Member States to provide co-funding is an important factor. ${ }^{121}$ This would

115 OJ [1992] L215/85, art 3. Member States could either divide their territories into particular zones, within which separate measures would apply, or adopt one central measure that would apply throughout their territory.

116 Council Regulation 1257/99 (OJ [1999] L160/80), Art 22.

117 Ibid, art 23.

$118 \mathrm{Ibid}$, art 24. Member States are required to calculate the payments on the basis of the income that farmers will forego by entering the scheme, any additional costs that will result from the environmental commitments given by those farmers and also the need to provide a financial incentive to attract farmers into the scheme.

119 See the evidence given by Mr Rheinhard Priebe (Head of the Agri-Environment Programme, European Commission) to the House of Commons Agriculture Committee- House of Commons Agriculture Committee 2nd Report, Environmentally Sensitive Areas and Other Schemes Under the Agri-Environment Regulation, Vol II, HC-45II (1997), p 273.

120 Court of Auditors, supra n 82, p 18.

121 Ibid, p 14. 
help to explain, for example, why Austria, despite having only 2 per cent of the European Union's farmland, managed to secure 21 per cent of the European Union's expenditure on agri-environmental land management schemes. ${ }^{122}$ Indeed the European Commission had previously noted that five Member States accounted for some 86 per cent of all Community expenditure on these schemes. ${ }^{123}$

\section{The Agri-Environmental Land Management Scheme in Northern Ireland and the Republic of Ireland}

A divergence of approach is certainly evident in relation to the agrienvironmental land management schemes contained within the rural development plans implemented by Northern Ireland and the Republic of Ireland. In Northern Ireland the measures available depend upon whether farms are located within areas designated as being 'Environmentally Sensitive Areas.' The Agriculture (Environmental Areas) Order (NI) 1987 gave the then Department of Agriculture for Northern Ireland ('DANI'), with the consent of the Department of Finance and Personnel, the power to designate such areas. ${ }^{124}$ These designations could be made where DANI believed them to be desirable in order to:

(1) Conserve and enhance the natural beauty of an area; or

(2) Conserve the flora and fauna or geological features of an area; or

(3) Protect buildings or other objects of archaeological, architectural or historic interest in the area. ${ }^{125}$

There are presently five areas designated as being Environmentally Sensitive Areas:

(i) The Mourne Mountains and Slieve Croob;

(ii) The Antrim Coast, Glens and Rathlin Island;

(iii) West Fermanagh and Erne Lakeland;

(iv) The Sperrin Mountains;

(v) Slieve Gullion. ${ }^{126}$

Altogether these areas comprise some 20 per cent of the agricultural land area of the province. ${ }^{127}$ All farmers located within these designated areas

122 Ibid.

123 European Commission, Report From the Commission to the Council and the European Parliament on the application of Council Regulation 2078/92 on agricultural methods compatible with the requirements of the protection of the environment and maintenance of the countryside, COM (1997) 620 Final, p 15. The Member States concerned were Austria, Germany, France, Finland and Italy.

124 SI 1987/458 as amended by the Agriculture (Environmental Areas) (Amendment) Regulations (NI) 1994 (SI 1994/419).

125 Ibid, art 3.

126 See the Environmentally Sensitive Areas Designation Order (NI) 2001 (SI 2001/269). 
may apply to DARD to join the Environmentally Sensitive Areas ('ESA') scheme. For farmers who are located outside these designated areas, Northern Ireland's rural development plan provides for a Countryside Management scheme to be available. This scheme was implemented by the Countryside Management Regulations (NI) 2001. ${ }^{128}$ The scheme is available to farmers whose farms contain one of the following priority habitats or features:

(i) semi-natural grasslands;

(ii) wetlands;

(iii) upland breeding wader sites;

(iv) moorland;

(v) lowland raised bog;

(vi) coastal farmland;

(vii) archaeological features;

(viii) parkland;

(ix) inter-drumlin loughs. ${ }^{129}$

In contrast to the two-tier system that operates in Northern Ireland, DAF in the Republic of Ireland has introduced one agri-environmental scheme, the Rural Environment Protection Scheme ('REPS'), which is available to farmers nationwide. ${ }^{130}$

In Northern Ireland farmers enter an ESA or Countryside Management agreement for ten years, though either the farmer or DARD may terminate the agreement after five years. In contrast, a REPS agreement has a duration of five years. Distinctions can also be drawn between the commitments required of farmers under these agreements.

In both Northern Ireland and the Republic of Ireland participating farmers are required to observe a number of entry-level commitments in return for receiving agri-environmental payments. In Northern Ireland, the ESA and Countryside Management schemes both set out general commitments that must be observed by all farmers who participate in either scheme. ${ }^{131}$ In contrast farmers participating in REPS will be required to comply with an agri-environmental plan that is drawn up specifically for their farm. ${ }^{132}$ This plan incorporates both general commitments that are imposed upon all participating farmers and also specific commitments that are drawn up in relation to their particular farm.

127 Department of Agriculture for Northern Ireland, Environmentally Sensitive Areas Implementing Agri-Environment Regulation (EEC) No. 2078/92 in Northern Ireland (1998), p 5.

128 SI 2001/43.

129 Ibid, reg 2 and Sch 3.

130 See Department of Agriculture, Food and Rural Development: The Rural Environment Protection Scheme (1999).

131 Environmentally Sensitive Areas Designation Order (NI) 2001, art 4(1) and Sch 2; Countryside Management Regulations (NI) 2001, reg 3(2)(a) and Sch 1.

132 See Department of Agriculture and Food, supra $\mathrm{n} 130$. 
In addition to entry-level commitments, farmers in both jurisdictions can agree to observe additional commitments in return for receiving further payments. In Northern Ireland, the ESA and Countryside Management schemes each provide for farmers to receive further payments in return for accepting additional obligations in relation to the management of the habitats of specific fauna and flora identified in each scheme. ${ }^{133}$ In the Republic of Ireland, REPS also provides for similar payments, but only in relation to areas of farmland that have been designated as being either of national conservation importance, such as National Heritage Areas and commanages, or as areas of Community importance, such as Natura 2000 sites. $^{134}$ Additionally REPS provides for farmers to receive additional payments for a number of other purposes. Farmers can receive such payments in return for agreeing to rear local livestock breeds that have been recognised by the Community as endangered species, for providing public access to their land for leisure purposes or for either converting to organic farming or agreeing to continue as organic farmers. ${ }^{135}$ No equivalent to these latter measures is available to farmers in Northern Ireland under the ESA or Countryside Management schemes, though a separate measure does provide financial support to farmers who convert to organic farming. ${ }^{136}$ This latter measure is also part of Northern Ireland's rural development programme.

Distinctions can also be drawn between the schemes in other ways. For example, farmers participating in REPS will be required to conduct particular capital works, such as fencing off all watercourses that are adjacent to their lands and maintaining all boundary and roadside fences, hedges and stonewalls. ${ }^{137}$ Additionally they may be required to conduct repairs to animal houses or waste storage facilities. These obligations form part of the commitments that participating farmers give in return for receiving basic payments under the scheme. Neither the ESA nor the Countryside Management schemes impose similar capital requirements upon farmers in Northern Ireland. However, both the ESA and Countryside Management schemes do make provision for additional payments to be made to farmers who agree to undertake particular projects upon their farms. Projects recognised for this purpose include the restoration of field boundaries and the erection of protective fences. ${ }^{138}$ The different approach to capital works in both Northern Ireland and the Republic of Ireland may partially be explained by the differing levels of payment that are available to farmers who participate in these schemes. In the Republic of Ireland farmers participating in REPS currently receive a basic payment, in return for accepting entry level commitments, of $€ 165$ per hectare on farms of up to twenty hectares and $€ 151$ per hectare on holdings over that size. ${ }^{139}$ In the latter situation these

133 Environmentally Sensitive Areas Designation Order (NI) 2001, art 4(4) and Sch 4; Countryside Management Regulations (NI) 2001, reg 3(4)(d) and Sch 3.

134 Department of Agriculture, Food and Rural Development, The Rural Environment Protection Scheme (1999), p 48.

135 Ibid, pp 53-61.

136 See the Organic Farming Regulations (NI) 2001 (SI 2001/5).

137 Department of Agriculture, Food and Rural Development, supra n 134, p 27 and p 33.

138 Environmentally Sensitive Areas Designation Order (NI) 2001, reg 4(4) and Sch 5; Countryside Management Regulations (NI) 2001, reg 3(4)(d) and Sch 5.

139 Department of Agriculture and Food, Schemes and Services 2003 (2003), p 54. 
payments are available on up to forty hectares, though participating farmers whose farms exceed forty hectares in size will be required to implement the scheme on their entire farms. ${ }^{140}$ In contrast in Northern Ireland, the level of the basic payments received by farmers participating in the ESA or Countryside Management schemes varies according to whether their land is classified by DARD as being unimproved, improved or arable land. Farmers receive up to $£ 30$ per hectare in respect of unimproved land and up to $£ 25$ per hectare in relation to improved or arable land. ${ }^{141}$ In any case, each of these schemes imposes a ceiling of $£ 1,500$ per annum upon the payments that will be made to farmers in Northern Ireland in respect of entry-level commitments. ${ }^{142}$

\section{Other Aspects of Rural Development Relevant to Agriculture}

Aside from agri-environmental land management schemes, other contrasts can also be drawn between the rural development plans implemented by Northern Ireland and the Republic of Ireland. Some 70 per cent of all agricultural land in Northern Ireland, and 75 per cent of that in the Republic of Ireland, had been designated as being agriculturally less favourable. ${ }^{143}$ These areas had previously benefited from the Community's less favourable area scheme, described above. It is perhaps therefore no surprise that both the Northern Ireland Executive and the government of the Republic of Ireland chose to continue to make such payments to farmers within these areas. These payments are now implemented in Northern Ireland through the Less Favoured Area Compensatory Allowance scheme and in the Republic of Ireland by the Disadvantaged Areas Compensatory Allowance scheme. ${ }^{144}$ These schemes are required to comply with a number of criteria set out in Council Regulation 1257/99. Consequently similarities can be drawn between the schemes adopted in both Northern Ireland and the Republic of Ireland. For example, both require payments to farmers to be based upon the number of hectares that they farm. ${ }^{145}$ Equally they both require farmers to

140 Additionally, farmers whose farms contain designated target areas, such as National Heritage Areas, Natura 2000 sites or commonages, can claim payments on up to 120 hectares where they agree to implement conservation management plans to maintain and regenerate these areas - Department of Agriculture and Food, supra n 130, p 48.

141 Environmentally Sensitive Areas Designation Order (NI) 2001, Sch 3; Countryside Management Regulations (NI) 2001, Sch 2.

142 Environmentally Sensitive Areas Designation Order (NI) 2001, art 4(5); Countryside Management Regulations (NI) 2001, reg 7(2).

143 In relation to Northern Ireland, see R Whatmough, "Changing Economics of Hill Farming" in JH Montgomery, JH McAdam and BJ Smith (eds), The High Country: Land Use and Land Use Change in Northern Irish Uplands (1988), p 81. For the Republic of Ireland, see Department of Agriculture, Food and Forestry, Annual Report of the Minister for Agriculture, Food and Forestry 1996, $\mathrm{p} 40$.

144 In Northern Ireland the Less Favoured Area Compensatory Allowance Scheme is currently implemented through the Less Favoured Area Compensatory Allowance Regulations (NI) 2003 (SI 2003/162). In the Republic of Ireland, the Disadvantaged Areas Compensatory Allowance is a non statutory scheme. For details of the latter scheme, see Department of Agriculture, Food and Rural Development, National Development Plan 2000-2006 (2001).

145 As required by art 14 of Regulation 1257/99. 
agree to farm that land for at least five years from the date of their first payment and to agree to observe good farming practices in order to protect the environment and to maintain the countryside. ${ }^{146}$

Council Regulation 1257/99 does, however, also confer sufficient discretion upon Member States to enable significant differences to exist between the Less Favoured Area Compensatory Allowance scheme and the Disadvantaged Areas Compensatory Allowance scheme. For example, participating farmers in both jurisdictions are required to observe codes of good farming practice. These codes, however, are developed nationally. Equally differences exist in the manner in which areas have been designated as being agriculturally less favourable. These differences reflect the methods which had been used to designate the areas that had benefited under the Community's previous less favoured area measures. In Northern Ireland, Less Favoured Area Compensatory Allowances will be paid to farmers located in areas that have been designated as being either 'Severely Disadvantaged' or 'Disadvantaged'. ${ }^{147}$ Contrastingly, in the Republic of Ireland, farmers will be entitled to receive Disadvantaged Area Compensatory Allowance if their land is located within an area that has been designated as being within one of four categories. These are that the land is 'more severely handicapped lowland', 'less severely handicapped lowland', 'mountain type grazing' or 'coastal land with specific handicaps'. ${ }^{148}$ In each case, the levels of payment received by farmers vary in accordance with the nature of the designation of their land. However, the level of payment equally differs between Northern Ireland and the Republic of Ireland. In Northern Ireland farmers will receive up to $£ 40$ per hectare in respect of land that has been designated as being 'Severely Disadvantaged' and up to £20 per hectare in respect of 'Disadvantaged' land. ${ }^{149}$ In contrast, in the Republic of Ireland, farmers whose lands are within areas designated as being 'severely handicapped lowland' are entitled to receive $€ 88.88$ per hectare, while those whose lands are located in areas designated as being 'less severely handicapped lowland' or as 'coastal areas with specific handicaps' are entitled to receive $€ 76.18$ per hectare. Additionally, farmers who farm land designated as 'mountain type grazing' are entitled to receive $€ 101.58$ per hectare on up to ten hectares of land and $€ 88.88$ per hectare in respect of additional land. Different provisions also apply in respect of a farmer's eligibility to such payments. In Northern Ireland, Less Favoured Area Compensatory Allowance will be paid in full on the first three hundred and fifty hectares of every farm, with payment being reduced to half the prescribed rate on the next one hundred and fifty hectares and to one-quarter of the prescribed rate in respect of any additional land. ${ }^{150}$ In contrast, in the Republic of Ireland, farmers are only entitled to receive Disadvantaged Area

146 Ibid.

147 See the Less Favoured Area Compensatory Allowances Regulations (NI) 2003, reg 7 and Sch.

148 Department of Agriculture and Food, Schemes and Services 2003 (2003), p 52.

149 Less Favoured Area Compensatory Allowances Regulations (NI) 2003, reg 7 and Sch. Payments of $£ 20$ per hectare will also be made in respect of common land which falls within either designation.

150 Less Favoured Area Compensatory Allowances Regulations (NI) 2003, reg 7. 
Compensatory Allowance on up to forty-five hectares of land. ${ }^{151}$ However, given the average sizes of farms in Northern Ireland and the Republic it can be observed that, in practice, farmers in the Republic of Ireland can be expected to benefit from more generous payments under this measure. ${ }^{152}$

Elsewhere, comparisons can also be made of the extent to which the Northern Ireland Executive and the government of the Republic of Ireland have chosen to implement other discretionary measures set out in Council Regulation 1257/99 within their rural development plans. For example, the Regulation continues to make provision for Member States to implement early retirement measures and also enables them to provide financial assistance for young farmers starting off in the profession. In the Republic of Ireland DAF has availed of the opportunity to implement both measures. ${ }^{153}$ Early retirement pensions are available to farmers aged between 55 and 66. Retiring farmers receive annual pensions of $€ 5,403$ plus $€ 338$ per hectare, up to a maximum of $€ 13,615$. The scheme is designed to encourage eligible farmers to transfer their farms to younger farmers who may also benefit from the payment of installation aid for young farmers. This latter scheme is available to farmers aged under 35 who are setting up in farming for the first time. Such farmers are eligible to receive a payment of $€ 9,523$ to help defray the expenses that they incur in so doing. In contrast, the Northern Ireland Executive has chosen not to implement either of these measures within its rural development plan. A recent report, however, has indicated that whilst farmers in Northern Ireland would welcome the introduction of both measures, a strong economic case only existed for a scheme which provided assistance for young farmers who were setting up in farming. ${ }^{154}$ It may therefore be that a future rural development plan may seek to incorporate this measure.

\section{Further Reform}

On $26^{\text {th }}$ June 2003 the Council of the European Union reached agreement upon a further package of reforms that will, in the near future, affect the operation of the CAP. In substance, this package continues to provide for national measures, concerning agricultural production and rural development, to operate within a common framework. In practice, however, that framework will provide even greater scope for national differences to evolve in relation to the operation of the CAP. Indeed, building upon the regionalisation of rural development planning, the new framework will also enable regional differences to evolve in the manner in which Community agricultural production measures are implemented within individual Member States.

151 Department of Agriculture and Food, Schemes and Services 2003 (2003), p 37.

152 As outlined in the introduction to this art, average farm size in Northern Ireland is 34.5 hectares and in the Republic of Ireland is 29 hectares.

153 See Department of Agriculture, Food and Rural Development, National Development Plan 2000-2006 (2001).

154 P Caskie, J Davis, D Campbell and M Wallace, An Economic Study Of Farmer Early Retirement And New Entrant Schemes For Northern Ireland (2002). 


\section{Direct Payments to Farmers}

The measures agreed upon by the Council have developed from proposals initially put forward by the European Commission. ${ }^{155}$ The legislation was published in the Official Journal on $21^{\text {st }}$ October 2003. ${ }^{156}$ Perhaps the most radical aspect of the Commission's initial proposals was that they envisaged that the direct payments which farmers currently receive through the operation of several common organisations, should be replaced by a single payment. Additionally the Commission proposed that this payment should be decoupled from production so that, for example, the entitlements of livestock farmers would not be linked to the size of their current livestock herds. The Commission noted that such a move towards decoupled payments would complete the shift in the focus of Community support measures, from product to producer, which had begun with the introduction of partially decoupled payments in 1992 and 1999.157 Additionally, the Commission suggested that the fact that these payments were not determined by farmers present production levels would also help to integrate environmental protection considerations into the CAP. ${ }^{158}$ Farmers would have less incentive to maximise their production levels, thereby removing a source of potential damage to the environment. Today Council Regulation $1782 / 2003$ provides for a single payment scheme to be introduced by $1^{\text {st }}$ January 2005. ${ }^{159}$ Equally, 'where specific agricultural conditions warrant', the Regulation authorises Member States to delay the introduction of this single payment until $1^{\text {st }}$ January in either 2006 or $2007 .{ }^{160}$ This latter provision serves to illustrate the degree of flexibility that will be introduced by this regulation.

The single payment scheme introduced by Council Regulation 1782/2003 mirrors the Commission proposals in the sense that it is intended to apply instead of the various arable and livestock payments that are currently received by farmers. The payment is to be calculated upon an historic basis. For established farmers this means that it will be based on an average of the total payments received by those farmers, under the present payments regime, in the calendar years 2000, 2001 and 2002. ${ }^{161}$ Each Member State will also be required to ensure that the total amount expended upon the single payment scheme within that Member State does not exceed a national ceiling established by the Regulation. ${ }^{162}$

The measures introduced for the new single payment scheme do, however, depart from the initial Commission proposals in several respects. It is in this area that there will be considerable scope for both national and regional

155 See European Commission, Mid Term Review For Sustainable Agriculture, COM (2002) 394 Final and European Commission, A Long Term Perspective For Sustainable Agriculture, COM (2003) 23 Final.

156 OJ [2003] L270.

157 European Commission, Mid Term Review For Sustainable Agriculture COM (2002) 394 Final, p 19.

158 Ibid.

159 OJ [2003] L270/1, arts 33 and 156.

160 Art 71.

161 Art 38

162 Art 41. 
differentiation. Member States must decide, by $1^{\text {st }}$ August 2004 at the latest, whether they wish to apply the single payment scheme on a regional or a national basis. ${ }^{163}$ In the United Kingdom, the government has announced that the scheme will be introduced on a regional basis with agriculture departments in England, Scotland, Wales and Northern Ireland each introducing their own measures. ${ }^{164}$ Member States, such as the United Kingdom, which adopt a regional approach will be required to divide the national ceiling, established for the single payment scheme, into separate regional ceilings. ${ }^{165}$ Thereafter regional agricultural authorities will have several options in relation to the manner in which the single payment scheme might operate within their region.

One option available is that, rather than implementing a single payment scheme that is based upon actual historic production, regional authorities may elect to calculate the payments made to farmers on the basis of a common regional rate. This would arise because Council Regulation $1782 / 2003$ enables the single payment to be calculated by dividing the monies available amongst farmers purely on the basis of the amount of eligible land that they farm. ${ }^{166}$ Equally, as a variation to this area based approach, the Regulation would authorise a situation in which the level of payment received by each farmer would vary, not only in accordance with the amount of eligible land that each farmed, but also according to the number of hectares that were under grassland, permanent pasture or other agricultural use in 2003. ${ }^{167}$ This would enable national or regional authorities to place different financial values upon each land use and to calculate individual payment entitlements on that basis.

Alternatively, Council Regulation 1782/2003 would also enable national or regional agricultural authorities to introduce a single payment scheme that operates alongside slimmed down versions of present arable area payments and livestock headage payments. ${ }^{168}$ This would require them to reduce the level of the payments that they would otherwise have made under the single payment scheme and to pay out the monies saved by this reduction as arable area payments and livestock headage payments. This hybrid scheme would continue to link the level of payments made to livestock farmers to their present livestock numbers. The Commission in its proposals for a decoupled single payment never envisaged such a situation.

Council Regulation 1782/2003 enables national and regional authorities to consider a variety of options. For example, they would be entitled to introduce measures that enabled them to continue paying up to 25 per cent of the portion of the national or regional ceiling for the single payment scheme that related to current arable area payments as an arable area payment. ${ }^{169}$ Similarly, national or regional authorities are also entitled to retain up to 50

163 Art 58.

164 See Department of Agriculture, Food and Rural Affairs, "Third consultation on options under the CAP reform agreement."

165 Art 58(3).

166 Art 59.

167 Art 61

168 Art 64

169 Art 66. 
per cent of the portion of the national or regional ceiling that corresponds to the headage payments currently paid to sheep farmers. ${ }^{170}$ They would then be able to pay these monies to farmers, on the basis of the number of eligible sheep that they owned, in a manner similar to the current sheep annual premium scheme. National or regional agricultural authorities would also be entitled to retain, to varying degrees, the direct payments currently made to beef farmers. ${ }^{171}$ They are entitled to retain up to 100 per cent of the portion of the national or regional ceilings that correspond to slaughter premiums paid to farmers in respect of calves. Again these monies would then continue to be paid to farmers in a manner that was equivalent to the present calf slaughter scheme. However, Council Regulation 1782/2003 also goes on to provide national and regional agriculture authorities with further discretion in relation to the payments to be made to beef farmers. ${ }^{172}$ They are entitled to retain up to 100 per cent of the portion of national or regional ceilings that correspond to suckler cow premiums and up to 40 per cent of the portion that corresponds to the slaughter premium paid in respect of adult cattle. Alternatively they may retain up to 100 per cent of the portion of the national or regional ceiling that corresponds to this slaughter premium and also 75 per cent of the portion that corresponds to payments of beef special premium. In each case, should a national or regional agriculture authority exercise its discretion to implement one of these options, then the monies deducted from the national or regional ceiling will continue to be paid to farmers in a manner which replicates the individual payment regimes currently operating under the common organisation relating to the production of beef and veal.

Indeed even beyond the provisions that are outlined above, Council Regulation 1782/2003 also enables Member States and their regions to exercise choices in relation to other aspects of the introduction of the single payment scheme. For example, Article 47(2) provides that the new dairy premium scheme, to be introduced over the period 2004-2007, will be incorporated into the single payment scheme from 2007. However, by way of derogation, Article 62 authorises Member States to include dairy premium payments within the single payment scheme, in whole or part, from 2005. Similarly, Article 69 authorises Member States to retain up to 10 per cent of the national ceiling fixed for the single payment scheme. The monies retained would then operate as a national envelope, with Member States being entitled to use these monies to make additional payments to encourage specific types of farming that are important for the protection or enhancement of the environment or for improving the quality and marketing of agricultural products.

It will quickly be apparent that these provisions provide both Member States and their regions with a very large discretion as to the manner in which direct payments should in future be made to farmers. It is very possible that in future broad differences may emerge in the practices adopted both by individual Member States and also by individual regions. At the time of writing, the respective agriculture departments in Northern Ireland and the

\footnotetext{
170 Art 67.

171 Art 68

172 Ibid.
} 
Republic of Ireland were conducting public consultations in order to determine the options that would be most appropriate for each jurisdiction.

\section{Cross Compliance}

The recent reforms to the CAP have also sought to take steps to further integrate environmental concerns into the Community's direct payment scheme. It has previously been observed that Council Regulation 1259/99 required Member States to link all direct payments made to farmers through the common organisations to a requirement that those farmers should respect appropriate environmental obligations. Equally, the Regulation gave Member States some discretion in choosing the most appropriate method through which this might be achieved. The European Commission has suggested that considerable scope existed for further improvement in relation to the measures actually adopted by Member States. ${ }^{173}$ In particular the Commission has noted that implementation of statutory requirements was "uneven" and that little use had been made of cross compliance mechanisms, in which farmers' eligibility to receive direct payments is linked to an obligation to observe specific environmental conditions. ${ }^{174}$ Under Council Regulation, 1872/2003 all Member States, however, will now be required to implement this latter option, by introducing cross compliance measures. ${ }^{175}$ Equally, these Regulations will expand the obligations placed upon farmers beyond purely environmental considerations. From $1^{\text {st }}$ January 2005, in order to remain eligible to receive direct payments, farmers throughout the Community will be required to comply with particular European Community legislation concerning the protection of the environment and the identification of animals. ${ }^{176}$ From $1^{\text {st }}$ January 2006, these farmers will also be required to ensure that their agricultural practice also complies with several European Community measures concerning public, animal and plant health and the notification of diseases. ${ }^{177}$ Additionally, from $1^{\text {st }}$ January 2007, these farmers will be required to comply with European Community

173 European Commission, Mid Term Review for Sustainable Agriculture, COM (2002) 394 Final, p 8.

174 Ibid.

175 Art 3.

176 Art 4 and Annex III. The environmental protection legislation is Council Directive 79/409 on the conservation of wild birds; Council Directive 80/68 on the protection of groundwater against pollution by dangerous substances; Council Directive $86 / 278$ on the protection of the environment from sewage sludge used in agriculture; Council Directive 91/676 on the protection of waters against pollution caused by nitrates from agricultural sources; and Council Directive 92/43 on the conservation of natural habitats and of flora and fauna. The animal identification legislation is Council Directive 92/102 on identification of animals; Commission Regulation 2629/97 implementing provisions for the identification and registration of cattle; and Council and Parliament Regulation 1760/2000 on the labelling of beef and beef products.

177 Ibid. The Community legislation is Council Directive 91/414 on the marketing of plant protection products; Council Directive 96/22 prohibiting the use of particular substances in livestock farming; Council and Parliament Regulation 178/202 concerning food safety; Council and Parliament Regulation 999/2001 on the prevention, control and eradication of BSE; Council Directive 85/511 on control of foot and mouth disease; Council Directive 92/119 on swine vesicular disease; and Council Directive 2000/75 on the control of bluetongue. 
legislation on animal welfare. ${ }^{178}$ In each case the relevant legislation is specified in the regulation. These measures may promote greater uniformity of practice, in the sense that farmers throughout the Community will be required to ensure that their practice complies with the same Community legislation. However, Council Regulation 1782/2003 also goes further. As a further condition of receiving direct payments, farmers will also be required to maintain their lands in "good agricultural condition."179 This obligation will take effect from $1^{\text {st }}$ January 2005 . It seeks to ensure that farmers respect at least minimum requirements in order to achieve good agricultural conditions established by their Member State or regional authorities. The Regulation establishes a framework that identifies both the particular issues that these national conditions should seek to address ${ }^{180}$ and also the nature of the standards they should require farmers to meet. ${ }^{181}$ Within this framework considerable scope exists for divergent practice to evolve in the manner in which these good agricultural conditions develop. Indeed this is acknowledged by the regulation, which requires that Member States in establishing these national conditions should take into account "the specific characteristics of the areas concerned, including soil and climatic conditions, existing farming systems, land use, crop rotation, farming practices and farm structures." 182

\section{Modulation and Degression}

Council Regulation 1782/2003 will now introduce a system of compulsory modulation from 2005. This aspect of the Regulation will affect all farmers who receive more than $€ 5,000$ per annum in direct payments through the operation of the common organisations. ${ }^{183}$ A deduction of 3 per cent will be made to these payments in 2005, rising to 4 per cent in 2006 and reaching a ceiling of 5 per cent in the period 2007-2012. ${ }^{184}$ The monies saved through these deductions will then be made available to Member States as additional Community support for rural development measures. ${ }^{185}$ The actual amount allocated to each Member State will be decided by applying criteria that take account of their agricultural area, levels of agricultural employment and gross domestic product. ${ }^{186}$ However, each Member State is guaranteed to

178 Ibid. The Community legislation concerned is Council Directive 91/629 on the protection of calves; Council Directive 91/630 on the protection of pigs; and Council Directive $98 / 58$ on the protection of animals kept for farming.

179 Art 5.

180 These are identified in Annex IV as protecting the soil from erosion, maintaining levels of soil organic matter and ensuring a minimum level of maintenance to avoid habitat deterioration.

$181 \mathrm{Ibid}$. For example, in relation to preventing soil erosion the annex requires that the national conditions should introduce standards detailing minimum soil cover, minimum land management conditions and conditions regarding the retention of terraces.

182 Art 5(1)

183 Arts 10 and 12(1).

184 Art 10(1).

185 Art 10(2).

186 Art 10(3). 
receive at least 80 per cent of the total modulation funds that are generated there. ${ }^{187}$

In addition to the deductions to be made in respect of modulation, the European Commission had also proposed that additional deductions should also be made from direct payments under a measure referred to as 'degression'. The Commission had proposed that money saved by this measure should be retained by the Community to enable it to finance future market needs and reforms and to help ensure that Community expenditure upon agriculture would stay within financial ceilings set by the European Council in October 2002. The European Commission had proposed that the degression deduction should also apply to all farmers receiving $€ 5,000$ or more per annum in direct payments. As shown in the table below, it was proposed that the percentage reduction would increase over the period 20072012 and that higher deductions would be made in the case of farmers who received more than $€ 50,000$ per annum in direct payments. Ultimately, however, the European Commission's proposals for a degression were not accepted by the Council.

\section{Degression Proposals}

\section{Direct Payments}

Level of Annual Payments

$$
€ 5001-€ 50,000
$$

Above $€ 50,000$

\section{Percentage Reduction Proposed}

$\begin{array}{lllllll}2006 & 2007 & 2008 & 2009 & 2010 & 2011 & 2012\end{array}$

The reaction of the governments of the United Kingdom and the Republic of Ireland to the European Commission's proposals for the introduction of compulsory modulation and degression measures, illustrate the fact that broad distinctions continue to exist in the approach adopted by both to the CAP. As noted previously in this article, the principle of modulation has already been implemented throughout the United Kingdom. Indeed the report of the Policy Commission on the Future of Farming and Food (also known as 'the Curry Report') had recommended that, in the event that the Community had not delivered a substantial reform of the CAP, the United Kingdom should consider raising the degree of modulation to the maximum 20 per cent authorised by Council Regulation 1259/99. The United Kingdom government, however, was opposed to the European Commission's initial proposal to fix a ceiling of $€ 300,000$ upon the annual value of overall direct payments that could be made to any one farmer. ${ }^{188}$ This opposition stemmed directly from the larger farm structures that exist in parts of Great Britain. It has been estimated that the Commission's proposal would have affected six hundred farmers in Great Britain, four in the Republic of Ireland and none in Northern Ireland. ${ }^{189}$ In contrast to the United Kingdom government, the

187 Ibid.

188 Government Reply to the Third Report of Session 2002-2003 from the Environment, Food and Rural Affairs Committee, HC-615, p 6.

189 In respect of Great Britain and the Republic of Ireland, see the Environment, Food and Rural Affairs Committee, $3^{\text {rd }}$ Report of Session 2002-2003: The Mid Term Review of the Common Agricultural Policy, HC-151, p 28. In respect of 
government of the Republic of Ireland has been opposed to the concept of modulation. For example, the Minister of Agriculture and Food expressed the view that "supporting farming is a better way of supporting rural villages and towns than modulation." 190

Similarly, in relation to the Commission's proposals for degression, the United Kingdom government expressed general support. ${ }^{191}$ Its major concern was that the Commission's proposals for a higher rate of degression would discriminate against the United Kingdom, due to its larger than average farm structures. ${ }^{192}$ The United Kingdom government had expressed a preference for a flat rate system that would apply equally to all farmers. ${ }^{193}$ In contrast the government of the Republic of Ireland was opposed to the proposals regarding degression. ${ }^{194}$ Overall, in terms of the differing approaches of the two governments, the position was summed up as follows by the Minister of Agriculture and Food, in evidence given to the House of Commons Environment, Food and Rural Affairs Committee:

"We approach this whole matter of farming and agriculture from a slightly different perspective, because of the importance [of agriculture] to the overall economy."

\section{Rural Development Policy}

The Community's spending upon rural development measures has today increased to a position in which it now accounts for some 16 per cent of the Community's total expenditure upon agriculture. ${ }^{195}$ The introduction of compulsory modulation will in future lead to an even greater portion of CAP expenditure being allocated to rural development. It is against this background that the Community has sought to increase further the level of discretion that is provided to national and regional agriculture authorities in relation to rural development planning. Council Regulation 1783/2003 has amended Council Regulation $1259 / 99$ to add to the menu of measures that these bodies may include within their rural development plans. ${ }^{196}$ Council Regulation 1783/2003 will enable national authorities to introduce temporary investment support measures that assist farmers in meeting the new environment, hygiene and animal welfare standards introduced by Council Regulation 1782/2003. These payments can be made available for up to five years from the date on which the particular standards come into effect. National agriculture authorities will also be able to provide support measures

Northern Ireland, see Department of Agriculture and Rural Development, "Minister Rodgers writes about the Commission's mid term review proposals," Press Release 228/02, $10^{\text {th }}$ July 2002.

190 Environment, Food and Rural Affairs Committee, $3^{\text {rd }}$ Report of Session 2002 2003: The Mid Term Review of the Common Agricultural Policy, HC-151, p 7.

191 Government Reply to the $3^{\text {rd }}$ Report of Session 2002-2003 from the Environment, Food and Rural Affairs Committee, HC-615, p 4.

192 Ibid, p 9.

193 Ibid.

194 See Department of Agriculture and Food, Annual Review and Outlook for Agriculture and Food 2002-2003 (2002), p 74.

195 European Commission, Mid-Term Review for Sustainable Agriculture, COM (2002) 394 Final, p 9

196 OJ [2003] L270/71. 
for farmers who enter into an agreement, lasting at least five years, under which they commit themselves to providing improvements to animal welfare standards on their farms. Additionally the Regulation will also enable national authorities to provide financial support to farmers who participate in either Community or national schemes designed to promote food quality. In each case these new measures will operate within the common framework provided by Council Regulations 1782/2003 and 1257/1999. However, they will equally provide national authorities with even greater choice in developing their rural development plans.

\section{CONCLUSION}

The CAP initially developed into a policy that was composed of two distinct elements, or pillars. In the first pillar Community regulations established common organisations in an attempt to create unified market and price policies for particular agricultural commodities. The second pillar of the policy contained Community measures that were designed to tackle the structural problems which existed within European agriculture. In 1973, when Northern Ireland and the Republic of Ireland joined the Community, the regulations establishing the common organisations might, at face value, appear to have established common laws governing agricultural markets. In reality, however, the prevalence of cross-border smuggling between both areas shows that this had not been achieved. The lack of a common currency at that time, together with the existence of separate national rates of exchange for agricultural commodity prices, prevented a common policy from developing. At that time the Community's agricultural structural policy was in an embryonic state. However, national resistance helped to ensure that a 'common' structural policy never developed. Instead, in order to limit distortion in trade, the Community structural policy developed into a framework measure that provided Member States with broad discretion in tailoring this policy to national circumstances.

Today, in relation to agricultural production, separate agricultural exchange rates may have been abolished. However, the discretion given to Member States to link direct payments to appropriate environmental protection measures and to modulate these payments, means that distinctions continue to exist between measures adopted in Northern Ireland and the Republic of Ireland. The operation of national envelopes also enable distinctions to exist between Member States generally. Equally today, Community structural policy continues to provide a common framework within which Member States are afforded a broad discretion in deciding upon the individual measures that they adopt. As has been shown, this enables broad distinctions to exist between the measures adopted in Northern Ireland and the Republic of Ireland, and also elsewhere in the Community.

Looking to the future, the recent reform of the CAP would seem to have created a situation in which broad distinctions will continue to evolve in the operation of the common organisations within individual Member States. Furthermore, increasing variation can be expected within the rural development policies of particular countries and their regions. Greater scope will exist for decision-making, regarding the implementation of the CAP, to be devolved to regional levels. This may lead to a situation in which regional differences in the implementation of the CAP become increasingly common throughout the European Community. 